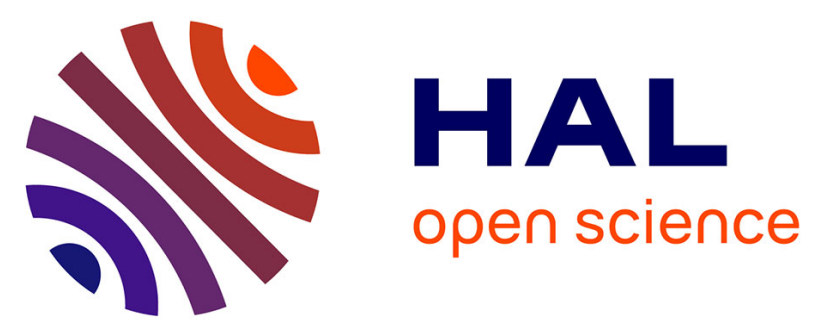

\title{
Reverse Logistics Route Selection Using AHP: A Case Study of Electronics Scrap from Pakistan
}

Fahad Mushtaq, Muhammad Shafiq, Matteo Mario Savino, Touqeer Khalid, Marialuisa Menanno, Ali Fahad

\section{- To cite this version:}

Fahad Mushtaq, Muhammad Shafiq, Matteo Mario Savino, Touqeer Khalid, Marialuisa Menanno, et al. Reverse Logistics Route Selection Using AHP: A Case Study of Electronics Scrap from Pakistan. IFIP International Conference on Advances in Production Management Systems (APMS), Aug 2018, Seoul, South Korea. pp.3-10, 10.1007/978-3-319-99704-9_1 . hal-02164854

\section{HAL Id: hal-02164854 \\ https://hal.inria.fr/hal-02164854}

Submitted on 25 Jun 2019

HAL is a multi-disciplinary open access archive for the deposit and dissemination of scientific research documents, whether they are published or not. The documents may come from teaching and research institutions in France or abroad, or from public or private research centers.
L'archive ouverte pluridisciplinaire $\mathbf{H A L}$, est destinée au dépôt et à la diffusion de documents scientifiques de niveau recherche, publiés ou non, émanant des établissements d'enseignement et de recherche français ou étrangers, des laboratoires publics ou privés. 


\title{
Reverse logistics route selection using AHP: A case study of electronics scrap from Pakistan
}

\author{
Fahad Mushtaq ${ }^{1}$, Muhammad Shafiq ${ }^{1,2 *}$, Matteo Mario Savino ${ }^{2}$, Touqeer Khalid ${ }^{1}$, \\ Marialuisa Menanno ${ }^{2}$, Ali Fahad ${ }^{1}$ \\ ${ }^{1}$ Department of Industrial Engineering, University of Engineering and Technology, \\ 47050 Taxila Pakistan \\ ${ }^{2}$ Department of Engineering, University of Sannio, 82100 Benevento, Italy \\ shafiqaatir1@gmail.com
}

\begin{abstract}
Selection of optimal route among available choices in the presence of various factors has been a prime focus in logistics. In this paper, Analytical Hierarchy Process (AHP) is used for selection of optimum route among available options for revere logistics of electronics scrap from Pakistan to the industry using End of Life (EOL) products as there raw material. The main objective of this study is to find out the optimal reverse logistic path for electronic scrap considering: cost of transportation, time of transportation, volume of goods to be transported, nature of goods (refurbished, recyclable or scrap), and financial value of the goods being transported. Recently developed China Pakistan Economic Corridor named as CPEC is also considered among available routes which are being analyzed. The results show that CPEC is the best possible route. In addition, the proposed mechanism also provides hierarchical list for the possible route preferences which helps in finding an alternate in case the best/better route isn't available due to some unavoidable factors.
\end{abstract}

Keywords: Reverse logistics, Supply chain, China Pakistan Economic Corridor (CPEC), Analytical Hierarchy Process (AHP).

\section{Introduction}

Logistics management has established to be a key factor in supply chains. Realization of customers' value has increased the role of reverse logistics (RL) as it can play a key role in customers' satisfaction. RL has not only been used by companies for returning of goods for the purpose of recycling/remanufacturing but also useful in warranty claims and rejections.

Over past few decades, the World is digitized and use of electronic gadgets has increased exponentially. This development has given birth to an anti-climactic waste element known as electronic scrap [1]. The most interesting thing that differentiate such type of scrap from other industrial scrap is that it consists of hazardous but expensive metals. The recovery of these metal can be useful. Pakistan being more close to china and a good consumer market for electronic appliances and gadgets is facing environmental issues [2]. In China, there are various facilities that can recycle this electronic scrap and reuse it as raw material, thereby, saving cost and making envi- 
ronment clean. China is the major producer of electronic products so it is also largest user of all raw and auxiliary materials in the electronic industry [3-4]. In this way, China is responsible for almost $70 \%$ of the electronic waste. Chinese goods are supplied using different trade routes. CPEC is the latest development in one-belt-oneroad initiative. This is indeed the shortest way, however, mostly used for downstream transportation of goods. There is a huge potential to use this route for upstream transportation of electronic wastes, back to China [5].

In this paper, optimal reverse logistics route is determined for electronic scrap using AHP. Reverse logistics is upstream movement of products that can be due to warranty claim, repair, reclaimed or remanufactured. In few cases, parts of products are reused to save cost. Concept of disposable, especially, for electronic scrap is a major issue being faced by many countries. Pakistan being a developing country is facing this issue at highest possible level as it has become a dumping state for used electronics from all over the world (USA, EUROPE, and GULF). Cheaper Chinese products are another source of huge amount of Electronic waste. This paper focuses on finding optimal route for transportation of these products to proper disposed-off destinations for maximum gain.

\section{Literature Review}

Return type in reverse logistics is important because it shows interest of the repairing, refurbishing or remanufacturing industry. Obsolete market (ebay.com, taobao.com etc.) resell huge amount of used, obsolete parts and their buyer are present all over the world. Major return types categories are: (i) end of life, (ii) end of use, and (iii) reusable returns [6]. End of life return $(E O L)$ is the equipment and machinery used up to a specified time and dispose either at end of documented life or when there is an up gradation to latest versions [4]. End of use return is used when instead of buying machinery or equipment some companies prefer to get it on lease or rent and after specified period they need to be returned, e.g., construction industry [7, 8]. Reusable items are reusable parts of the scrapped machinery is scrapped [9]. Recovery of parts started right from where the machinery is scrapped. The requirements of the firms are usually different. For instance, those who are interested in metallic scrap are not bothered about electrical items. Those interested in instrumentation don't consider metallic scrap. Another important aspect is condition of the items which includes both working and cosmetic conditions [1].

Secondary markets for used products are subdivisions of the primary market and are intertwined. Pakistan can be termed as secondary market as for as electronics items are concerned. Used laptops, industrial products, control and instrumentation is largely being imported as scrap for saving cost of imports [7]. When collection is made at primary market and buyer is spread all over the world then secondary market is needed. The secondary market sell this scrap at a reasonably good price [6].

Reverse logistics lacks due attention in extant body of literature. More research work is required to solve problems related to reverse logistics [10]. The general processes associated with reverse logistics are described as follows (Fleischmann 
et al, 1997). Collection: The process of collecting used products at fixed locations for further processing is called collection. This includes purchasing of scrap, plant, machinery, and parts [11]. Inspection/separation: Process comprising segregation of goods and their classification as reusable, repairable, reclaimable etc. This helps us in assigning next destination to the products. At this stage: separation, disassembly, testing and then storage is carried out. Scrap is shredded and compressed to less volume for transportation ease [11]. Re-processing: The process of making a used product reusable, it can be in the form of: repair, part replacement, remanufacturing of parts, reassembly etc. [12]. Disposal: Finally, few products cannot be used due to less market value or huge maintenance cost (more than new in some cases) and need to be disposed. Disposal may include transportation, land filling and burning etc., keeping in view environmental safety regulations [13, 14]. Re-distribution: The process of transporting the recovered or repaired goods to its users is called re-distribution. This may include sales, transportation and storage activities $[15,16]$.

Reverse logistics is upstream movement of goods from end users to OEM [17]. Srivastava [18] defined reverse logistics as a process to plan, implement, and control the flow of returned products in order to recover value [19]. In short, reverse logistics is a process of returning products from the end user to supplier. The return can be because of warranty, incorrect delivery, end-of-lease or end-of-life [20].

The core activity of reverse logistics is collection of end of life products, faulty products, and scrap from market. Electronic products have huge number of users so collection of these items is complex as compare to the collection of equipment and machinery. Currently, majority of electronic products are being recovered by conventional means and repair/cannibalization industry is the largest source of electronic scrap collection from end users. As per environmental protection agency (EPA), "Professionals approximate a recovery of $24 \mathrm{~kg}(50 \mathrm{lb})$ of gold, $250 \mathrm{~kg}(550 \mathrm{lb})$ of silver, 9 $\mathrm{kg}(20 \mathrm{lb})$ of palladium, and more than 9,000 kg $(20,000 \mathrm{lb})$ of copper from reprocessing 1 million cell phones" $[19,20]$.

The amount of gold which can be recovered from one metric ton electronic scrap of personal computers is more than 17 ton of gold ore. In 1998, United States recovered an equivalent amount of gold from electronic scrap to the amount recovered from 2 million metric tons (Mt) of gold ore and waste [21 - 22].

Effect on environment due to electronic industry is huge as compare to other household products. A study conducted by United Nation Organization (UNO) established that the making of a computer and display screen takes at least $240 \mathrm{~kg}$ (530 pounds) of fossil fuels, $22 \mathrm{~kg}$ ( 48 pounds) of chemicals and 1.5 tons of water which is more than the weight of a rhinoceros or a car [23]. Recycling process of used aluminum saves $90 \%$ of energy required to mine fresh aluminum.

For a successful model of reverse logistics, it is necessary that there is a proper system of collection and upstream transportation. An algorithm that saves time and cost should be employed for the success of the model. The same can be studied from cou- 
rier/cargo services being used in e-commerce and online shopping [24]. Electronic waste has many materials which are costly (such as silver, gold) and also hazardous material for the environment (lead, tin etc.). The purpose is to recover all these materials to protect environment as well as to reduce cost of future products [25]. Recovering precious metals like Gold, Silver etc. is cheaper and environmental friendly [23, 26].

\section{Methodology}

The scope of reverse logistics isn't limited to get back defected and warranty products. Rather the aim green supply chain in reverse logistics is to deal with disposal of products and protect environment from hazardous chemicals during product disposal [27]. Hierarchy of reverse logistics for electronics waste is: (i) reuse, (ii) remanufacture, (iii) recycle, and (iv) disposal. [28]. However, this hierarchy isn't fixed for all types of products and may vary accordingly.

\section{China Pakistan Economic Corridor (CPEC)}

CPEC is a roadmap of regional linkage, the benefit of which is not only limited to China and Pakistan. The development of geographical connections have upgraded road, rail and air transportation system with recurrent and free exchanges of growth and contact. As a result, the exchange rate has been increased in terms of education, knowledge, culture, and business, resulting in peace, harmony, and development.

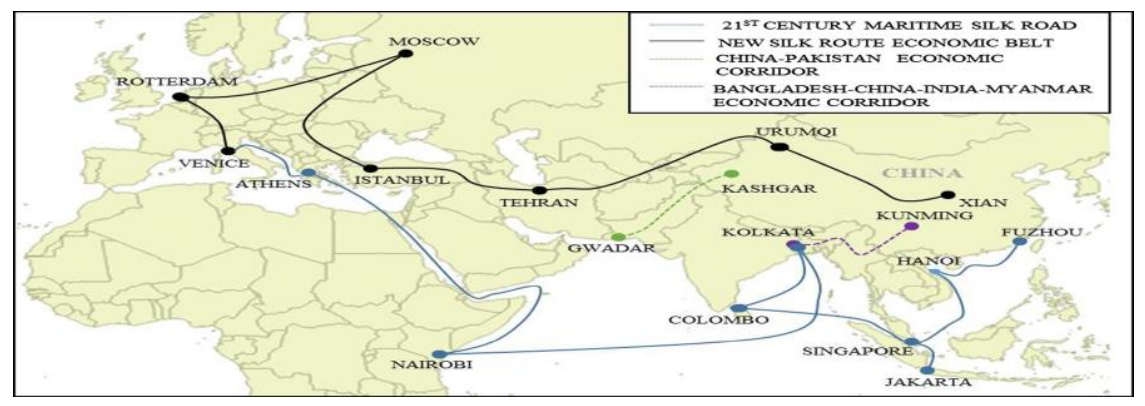

Fig. 1. Possible Routes

Figure 1 shows various international routes those can be used as an option for reverse logistics of electronics scrap from Pakistan. Indeed, we have five available routes, which are named Route 1 to Route 5 . We will assign different weights to these routes based on decision parameters. The five decision parameters selected to conduct this study are [31, 32]: (i) cost of Transportation, (ii) transportation time, (iii) volume of goods, (iv) nature of goods (Refurbished, Recyclable or Scrap), and (v) financial value of goods.

Assigning suitable weights, which are learned from the view of expert and literature, we may estimate preference value of the routes $[33,34]$. AHP is used to carry out analysis. AHP is useful and requires to draw a diagram by connecting dependent and independent nodes as shown in figure 2. The next step is to assign relative weights to the routes which are either based on data or experts' opinion. 


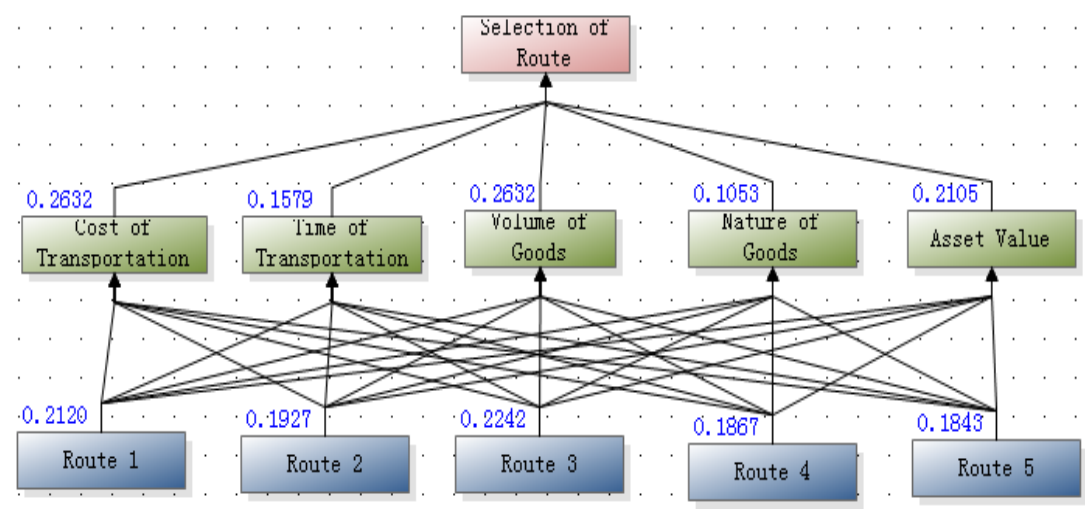

Fig. 2. Value of Different Routes for Reverse Logistics

\section{Results and Discussion}

Five factors have been considered in making decision using AHP to analyze different transportation routes. The weights/factors are provided by past data and opinion of the experts. The value for each routes using proposed AHP based mechanism is given in Table 1.

Here, we can see that value of Route 1 (CPEC Route) is highest. CPEC has various advantages and drawbacks as compare to other routes. One major drawback is that the products might have to travel more in China main land than in Pakistan. However, China is planning to develop western region which is close to Pakistan.

Table 1. Ranking Weights of Decisions

\begin{tabular}{lll}
\hline Sr. \# & Alternative & Calculated Weight \\
\hline 1 & Route 1 (Green) & 0.2242 \\
2 & Route 2 & 0.2120 \\
3 & Route 3 & 0.1927 \\
4 & Route 4 & 0.1867 \\
5 & Route 5 & 0.1843 \\
\hline
\end{tabular}

Transportation cost and time are two major factors that give edge to CPEC over other routes. In case of other routes, the volume of goods being reverse transported may be large as those routes are well established. However, time and transportation cost of CPEC is much lower than other routes [29, 30]. With maturity of the CPEC system and increase in forward logistics, the amount and types of the products available for reverse logistics will further increase which ultimately, increases the benefits of reverse logistics through CPEC.

Similarly, the weights of decision factors are tabulated below that are received after analysis using AHP. These are actually the advantages that CPEC provides for different decision parameters. With the development of western part of China, these decision parameters will be having higher values, i.e. become more advantageous. 
Table 2. Ranking Weights of the Elements in First Intermediate Layers

\begin{tabular}{ccc}
\hline Sr. \# & Alternative & Calculated Weight \\
\hline 1 & Volume of Goods & 0.2632 \\
2 & Cost of Transportation & 0.2632 \\
3 & Asset Value & 0.2105 \\
4 & Time of Transportation & 0.1579 \\
5 & Nature of Goods & 0.1053 \\
\hline
\end{tabular}

From Table 2, it is clear that volume of goods and cost of transportation have equal value. It means that CPEC with current assigned weights and decision parameters give equal importance to cost and weight. The more is the weight, more will be the transportation cost but in some situations this is not true. For bigger volume of goods and less weights, we ignore weights and cost is calculated based on volume. The table also explains that how closely different decision parameters are linked with each other.

The same model can be applied if we have more options of routes with different decision parameters. The decision parameters can vary based on type of goods to be transported. We can also use AHP-TOPSIS mixed approach for the calculation of preferred routes hierarchy. If available supply tracks for competitive market are unpredictable, the most feasible strategy to mitigate risk is to hold "emergency stock". However, if there exists a reliable path among available supply tracks to serve a competitive market, the superior risk mitigation strategy would be the economic (least costly) one.

\section{Conclusions and Recommendations}

This study addressed the design of a resilient supply chain network that targets to find out optimal route among the available options considering: (i) cost of transportation, (ii) time of transportation, (iii) volume of goods to be transported, (iv) nature of goods (refurbished, recyclable or scrap), and (v) financial value of goods to be transported. The main focus is to minimize the cost of transportation and time required for transportation. This study not only provide us an optimal path but also present results in such an order that all given options can be used in case of any unexpected situation. AHP is just an evaluation tool and the inputs or decision tables which compare different factors with each other are truly derived from past data and experts' opinion. As for CPEC, we don't have any past data, experts' opinions are used as input to find best possible solution.

The reverse and green logistics will help Pakistan to get rid of electronic waste in most productive way. In different cities of Pakistan, people are already working on electronic wastes and trying to recover as many components as they can. These recovered components are precious metals like gold, aluminum and other super conductor elements. Pull out electronic component market is very popular in Pakistan. This is another use of electronic scrap to recover good quality and cheaper electronic components.

The future of the world is moving towards electric vehicles (Computer on the wheels) and we are heading towards a huge amount of waste in the form of electronic 
gadgets and, especially, batteries being used in cars and other similar vehicles like electric bikes etc. So a special study for reverse logistics of batteries will not only help us in getting rid of scraps but cost saving as well. Another extension of this research can be AHP-TOPSIS based methodology considering additional factors. This will increase validity of results and interdependency of results can be verified

\section{References}

1. Kersten, W., Blecker T., Ringle C.M.: Sustainability in Logistics and Supply Chain Management. In: Proceedings of the Hamburg International Conference of Logistics (HICL). epubli, (2015).

2. Olariu, I.: Conceptual issues regarding reverse logistics. Studies and Scientific Researches. Economics Edition 18, 2344-1321 (2013).

3. Ni, H.-G., Zeng, E.Y.: Law enforcement and global collaboration are the keys to containing e-waste tsunami in China, ACS Publications (2009).

4. Kahhat, R., Kim, J., Xu, M., Allenby, B., Williams, E., Zhang, P.: Exploring e-waste management systems in the United States. Resources, Conservation and Recycling 52(7), 955-964 (2008).

5. Ninlawan, C., Seksan, P., Tossapol, K., Pilada, W.: The implementation of green supply chain management practices in electronics industry. In: Proceedings of the international multiconference of engineers and computer scientists. (2010).

6. Sarkis, J.: How green is the supply chain? Practice and research. Graduate School of Management, Clark University, Worchester, 1-40 (1999).

7. Wang, M., Liu, J., Wang, H., Cheung, W.K., Xie, X.: On-demand e-supply chain integration: A multi-agent constraint-based approach. Expert Systems with applications 34(4), 2683-2692 (2008).

8. Stock, J.R.: Development and implementation of reverse logistics programs. In: Annual conference proceedings, council of logistics management (1998).

9. Kumar, N., Chatterjee, A.: Reverse supply chain: Completing the supply chain loop. In: Cognizant 20-20 Insights (2011).

10. Baldé, C.: The global e-waste monitor 2014: Quantities, flows and resources2015.

11. Yang, H., et al., The impact of customer returns in a supply chain with a common retailer. European Journal of Operational Research 256(1), 139-150 (2017).

12. $\mathrm{Xu}, \mathrm{S} .$, Y. Liu, Chen, M.: Optimisation of partial collaborative transportation scheduling in supply chain management with 3PL using ACO. Expert Systems with applications 71, 173-191 (2017).

13. Sauer, P.C. Seuring, S.: Sustainable supply chain management for minerals. Journal of Cleaner Production 151, 235-249 (2017).

14. Ali, M.M., Babai, M.Z., Boylan, J.E., Syntetos, A.A.: Supply chain forecasting when information is not shared. European Journal of Operational Research 260(3), 984-994 (2017).

15. Sheu, J.B., Kundu, T.: Forecasting time-varying logistics distribution flows in the One Belt-One Road strategic context. Transportation Research Part E: Logistics and Transportation Review (2017).

16. Aljazzar, S.M., Jaber, M.Y., Moussawi-Haidar, L.: Coordination of a three-level supply chain (supplier-manufacturer-retailer) with permissible delay in payments and price discounts. Applied Mathematical Modelling 48, 289-302 (2017).

17. Rogers, D.S., Tibben-Lembke, R.: An examination of reverse logistics practices. Journal of business logistics 22(2), 129-148 (2001). 
18. Marulanda, J.M., Srivastava, A.: Carrier density and effective mass calculations in carbon nanotubes. physica status solidi (b) 245(11), 2558-2562 (2008).

19. Yuksel, H.: An analytical hierarchy process decision model for e-waste collection center location selection. Computers \& Industrial Engineering, 2009. CIE (2009).

20. Zhang, Y., Feng, Y.: A selection approach of reverse logistics provider based on fuzzy AHP. In: Fourth International Conference on Fuzzy Systems and Knowledge Discovery (2007).

21. Nnorom, I.C., Osibanjo, O.: Electronic waste (e-waste): Material flows and management practices in Nigeria. Waste Management 28(8), 1472-1479 (2008).

22. Lipan, F., Govindan, K., Chunfa, L.: Strategic planning: Design and coordination for dual-recycling channel reverse supply chain considering consumer behavior. European Journal of Operational Research (2017).

23. Schwarzer, S., De Bono, A., Giuliani, G., Kluser, S., Peduzzi, P.: E-waste, the hidden side of IT equipment's manufacturing and use (2005).

24. Pochampally, K.K., Gupta, S.M.: A business-mapping approach to multi-criteria group selection of collection centers and recovery facilities. In: IEEE International Symposium on Electronics and the Environment (2004).

25. Streicher-Porte, M., Widmer, R., Jain, A., Bader, H.P., Scheidegger, R., Kytzia, S.: Key drivers of the e-waste recycling system: Assessing and modelling e-waste processing in the informal sector in Delhi. Environmental impact assessment review 25(5), 472-491 (2005).

26. Babazadeh, R.: Optimal design and planning of biodiesel supply chain considering non-edible feedstock. Renewable and Sustainable Energy Reviews 75, 1089-1100 (2017).

27. Wu, X., Zhou, Y.: The optimal reverse channel choice under supply chain competition. European Journal of Operational Research 259(1), 63-66 (2017).

28. Chung, H., Lee, E.: Asymmetric relationships with symmetric suppliers: Strategic choice of supply chain price leadership in a competitive market. European Journal of Operational Research 259(2), 564-575 (2017).

29. Chen, J., Liang, L., Yao, D.Q., Sun, S.: Price and quality decisions in dual-channel supply chains. European Journal of Operational Research 259(3), 935-948 (2017).

30. Rezapour, S., Farahani, R.Z., Pourakbar, M.: Resilient supply chain network design under competition: A case study. European Journal of Operational Research 259(3), 1017-1035 (2017).

31. Tostivint, C., de Veron, S., Jan, O., Lanctuit, H., Hutton, Z.V., Loubière, M.: Measuring food waste in a dairy supply chain in Pakistan. Journal of Cleaner Production 145, 221-231 (2017).

32. Feitó-Cespón, M., Sarache, W., Piedra-Jimenez, F., Cespón-Castro, R.: Redesign of a sustainable reverse supply chain under uncertainty: A case study. Journal of Cleaner Production 151, 206-217 (2017)

33. Fahimnia, B., Jabbarzadeh, A., Ghavamifar, A., Bell, M.: Supply chain design for efficient and effective blood supply in disasters. International Journal of Production Economics 183, 700-709 (2017).

34. Chowdhury, M.M.H., Quaddus, M.: Supply chain resilience: Conceptualization and scale development using dynamic capability theory. International Journal of Production Economics 188, 185-204 (2017). 